\title{
A Critical Approach of the Administrative Security Model and the Security Policy of the Olympic Games 2004 (Athens)
}

\author{
Korontzis Tryfon (Corresponding author) \\ PhD Candidate, Panteion University of Social and Political Sciences of Athens \\ P.Ralli 228, 18454, Nikaia, Piraeus, Greece \\ E-mail: tmkoront@otenet.gr
}

Received: July 26, 2011

Accepted: August 9, $2011 \quad$ Published: December 1, 2011

doi: $10.5539 /$ res.v3n2p58

URL: http://dx.doi.org/10.5539/res.v3n2p58

\begin{abstract}
The aim of the present short article is to examine critically the security planning of the Olympic Games (OG) 2004 and particularly the manner in which it was developed and set into operation, the institutions and units involved, the command model which was developed so as to ensure their safe conduct as well as the problems revealed by the enforcement of the relative legislation and the legislation which was established for this specific event. The handling of the security of The OG 2004 to the Hellenic Police (HP), created the additional problem that the aforesaid institution would be in a position to have institutional opinion for actions and functions of other Competent Authorities, which were outside its normal-legal institutional framework, with the possible danger due to the lack of the analogous specialization for wrong decisions and choices to be made .
\end{abstract}

Keywords: Olympic Games, Administrative security model, Security policy, Olympic security, Strategic management, $\mathrm{C} 4 \mathrm{I}$

\section{Introduction}

The twenty-first century did not start in the best way for the world, at least as far as peace and security are concerned.

11 September 2001. The unprecedented and appalling terrorist attack on the twin towers in New York and at the Pentagon in Washington, changed dramatically the safety issues at a global level, signalling beyond any other manner the appearance of "unknown" and "asymmetric"(note 1) threats (Kathimerini reportaz, 23.09.2001).

After the 9/11 tragic events, a series of terrorist events took place in the years 2002-2003 like the bomb attacks in Tel Aviv by the Hamas, the suicide attack by a woman kamikaze in a concert in Moscow, etc. [Olympic Games Security Division (OGSD), Memorandum of exercise "ASPIS IRAKLEOUS"] which multiplied the anxiety for the safe performance of the OG 2004 (Mbrekis, 2008, pp. 136-137). Irrespective of the incentives that the terrorist attacks had, the creation of a new security environment should be taken into account, in combination with the specific features in the sensitive Balkan area. The particular geographical area was always characterized by intense nationality differences which led to territorial claims and conflicts with a recent example the conflicts in the area of former Yugoslavia during the decade of the 90s.

The above mentioned terrorist attacks put the authorities and systems of defence, under test, while at the same time the mechanisms for dealing with terrorism became more powerful and systems of prevention and deterrence were reinforced.

In support of the above, the security measures and the operational exercises carried out in Greece in the same period, (no comma) were intensified by the criminal prosecution authorities in cooperation with the Armed Forces (AF), in the context of the new doctrine of national security of Greece, so as to deal with hypothetical or real "Scenarios" of terrorist threats, according to information, notably by foreign intelligence services, for forthcoming shocks with international appeal in Greece. For example, the electronic readiness exercise "LERNAIA YDRA" or the information which was given in publicity in 29-5-2003, by the Minister of Mercantile Marine (Mr. Anomeritis G.), for a project of a terrorist attack of Al Qaeda terrorists with two high-speed boats in the Aegean sea against the ministers of commercial shipping and transport of the European 
Union (EU) who were supposedly aboard the passenger ferry "Eleutherios Venizelos" during an informal summit meeting (a mobilization deterrence took place without the labeling of vessels and terrorists).

The EU Presidency in 2003 undertaken by Greece, and the organization of the OG in 2004, contributed to Greece being rated $7^{\text {th }}$ among the countries which are facing terrorist threat. It should be noted that Greece had participation in the wars of the Persian Gulf (1991), of Afghanistan (2001-2002) and Iraq (2003) (note 2) resulting in being part of the circle of countries which are being under threat from Islamic terrorism (Laggaris, 2003).

Further to the above, the period after the collapse of the Soviet Union showed a vacancy of power in the region of Balkans and a search for a system of security and stability in the region. The existence of several particular ethnic minorities with strong nationalism, many political and social differences and the low economic level has led to a chronic rivalry. The Balkan environment is characterized by phenomena of instability, liquidity and a series of unforeseen threats to security (National Ramparts, 2006, pp. 26-47, ELESME, 2006, pp.12 -16).

This international environment affected the planning of security for the OG of 2004. The forecasts of the threats were widened. The security requirements escalated and the attention focused on a greater range of risks, such as attacks, suicide bombers, air CBRN threats, simultaneously or successively massively terrorist attacks etc.

It should be noted that Greece in the summer of 2003 succeed after 29 years of action to eradicate though accidentally- the terrorist organization November 17, which with its activity had caused many problems to the country as well as to the international image of Greece. This success, automatically offered confidence and in the mean time the opportunity that in the future Greece could speak with confidence on security issues (because of the success of the prosecuting authorities) but also she earned congratulations for its action from countries like the U.S. and the UK which were strongly interested in the dismantling of this terrorist organization.

Greece at the international level, always follows the UN resolutions (1991-Iraq, 2001-2/Afganistan) and it did not part at the "coalition of the willing" for combating operations outside of the institutional framework of UN (2003 Iraq). The policy at this point was contradictory as on the one hand she had provided facilities to allied countries (transportation of troops through the sovereign space, military bases in its territory where used by allied states (USA) e.g. and on the other hand had not provided military forces to act in Iraq. This fact that Greece had offered facilities to allies automatically meant that Greece had been the target by various Islamic fundamentalist organizations. In the above the active participation in the first war in Iraq and the disposal of forces in Afghanistan (note 3) should be taken into account.

In the light of the above, considerations for the preparation and organization of the OG took place at a time in which the security was nominated as the most important parameter for its successful hosting. To ensure the maximum success the doctrine of the total security was adopted. It meant: recognition of threats, analysis, composition and prevention or remedy. The security considerations were affected/ shaped by major wars, local or small area conflicts, asymmetrical threats, nuclear weapons, weapons including-agricultural destruction and non-state threats. All the above factors existed in the Balkan region other than major wars. The position of Greece, situated at a crossroads between two continents, between the West - East, North - South, in the southern part of the Balkans, by linking the Black sea with the Mediterranean, with a huge sea coastline and borders in the eastern Mediterranean, complicated further the security issues and raised the question on how should Greece make use of its resources to the greatest possible extent and to develop a national security (Platias 2002, pp. 82-87) which would lead to the successful performance of the OG 2004 (Ntokos, Tsakonas, 2005, pp. 21-194).

\subsection{Olympic Games Security Directorate (O.G.S.D.)}

A key milestone in the preparation for the $\mathrm{OG}$ - as far as the security is concerned - was the foundation and operation of the Olympic Games Security Directorate (OGSD). Its institutional framework was set up by Law "N. 2833/2000 (A' 150)", titled «Issues relating to the preparation for the Olympic Games and other clauses». In Article 5 of the above mentioned law, it was specified that the security of the OG was in the purview of the HP and a special Service, entitled "Olympic Games Security Directorate" established in the Headquarters of the HP.

According to its charter, the OGSD:

1) Was operating as an independent Central Service of the HP.

2) Was directly under the Head of the HP.

3) As a mission it had:

a.-the executive planning of the all measures regarding security, public order, and traffic of the Olympic and

Paralympics Games as well as for the Cultural Olympiad (Konstantinidis, 2003, pp.11-15), 
b.-the charge of ensuring the operational application of the security plans, and

c.-the coordination of services, agencies and other competent authorities which were involved in any way on the security of the OG (Manual "Olympic Security" 2003, pp. 85-90).

\section{A Theoretical Critical Review}

\subsection{Command, control, communication and integration systems (c4i systems)}

The Olympic industry, reflecting international and interconnected political-economic governmental, corporating interests, exploited real and perceived terrorist threats to prescribe extremely high security requirements. The Athens 2004 Olympics were used as a testing ground for the latest antiterrorist superpanoptic technology, which crucially failed to work. The central surveillance integration security system (C4I), planned by The Science Applications International Corporation, could not be implemented in time for the games. Hence, the security of the Athens Olympics was dependent on conventional means (Samatas 2007, pp. 220-238).

Samatas (2007) explains how the system C4I failed to work. In particular the OG 2004 was the first happening after the terrorist attack of $09 / 11$ and as it has been analyzed in the introduction it was preceded by several terrorist attacks, the War of the Gulf and more generally the islamic exclusive fundamentalism outbreak. The main targets were the states of the west and their citizens. Consequently in the OG 2004 citizens and athletes from various targets - states were grouped together and that created the need for a system which could help to avoid any terrorist threats.

Especially the project for C4I systems had the objective to cover the operational necessities of Olympic security predicted at in every administration level. The Operational Centre would have specific technical and operational opportunities, equipment and abilities, in order to facilitate and take the appropriate decisions regarding the administration, the coordination and the control of forces, the equipment and the management of incidents (Staurakakis M., 2009, p. 39).

In order for all the above to become a reality, the project had determined three autonomous but interdependent setting up component - systems:

a.-the system of administration support and making decision (CDSS),

b.-the information and security system (CIS) and

c. -the system of command centre - operational centre (CCS) [document 2004-1/17/1- $\rho \lambda \sigma \tau$ from 7-8-2002 OGSD/Command and Control Center].

The above system was not delivered and was not operational during the OG 2004 (Argirakis A., 2005). It was acquired by Greece on 29/03/2007 (Mbrekis 2008, pp. 145) and presented numerous operational problems. Consequently as it can be shown diagrammatically in table 1 the coordination, the ramification and the urgency in the administration and the decision system, in the system of communications and information technology and in the system of command centers - operational centers between services and operators did not work.

The 2004 Athens OG was the testing ground for the existing technology to prove that leading technological means are available to secure major international events. Unfortunately, technology so far cannot be used effectively in all cases without violating the legal framework, which was created to make the people feel that their personal data is protected. We have the example of the Greek Cell Phone Caper, which became a major case in the July 2007 issue of the spectrum magazine of The Institute of Electrical and Electronic Engineering (IEEE). This has been coded as 'the Athens affair' and shows how extremely smart hackers are with apparent inside information pulling off the most audacious cell-network infiltration ever. It was found that the cell phone of the Prime Minister of Greece was bugged, along with 100 other high-ranking officials and dignitaries of the government, including an employee of the US Embassy (Stavroulakis P. and Stavroulakis S. 2008, pp. 68-82).

A basic presumption of security is the security of communications. As mentioned earlier the system C4I which supported the administrative and at the same time the interprofessional security model, did not work. At the same time it is not revealed from somewhere that the agencies, bodies and competent authorities involved in the security of OG 2004 have made some upgrading of instruments in order to secure the communications, obviously based on the C4I system which was not installed at the appropriate time. This revealed that the communications at the highest institutional level were unsafe with obvious consequences. It can be noticed that the appliances staff of the US embassy were undercover, a country which is a target of terrorist organizations.

The shortcoming which was detected in the field of communications showed the vulnerability (note 4) of the security of the OG and of course in a period that the terrorist attacks from 2001 onwards did increase (Mbrekis 2008, pp. 136-137). 
The Colonel of the HP G. Galiatsos had stated that «we will never perhaps learn, if it was the planning which prevented us from a potential planned attack. But the result justifies our efforts. Nothing was coincidence, because nothing was left to chance. Eventually only those who dislike us believe in our luck, because only in this way can our success be explained, which is given and universally recognized», (G. Galiatsos, 2005, p. 69).

It is known that any performance can be measured at two levels: one level is the communication policy according to appropriate policies should convince citizens that all are progressing satisfactorily and secure. The second level is the operational which includes all the necessary design actions in order to prevent or to curb any unlawful energy. The fact that during the OG 2004 a terrorist attack did not take place does not necessarily mean that the planning was so good that it operated dissuasively. Furthermore it should be noted that the most recent crisis which had been confronted by Greece was the crisis of IMIA in 01/1996. That incident had proved that the management of crises systems was at least insufficient with non-separate roles between civil and military leadership and with full discrepancy in strategic and operational level to deal with the crises.

The cooperation between the AF and other responsible security agencies for the organization of the Olympic and Paralympics Games admittedly was excellent. This cooperation helped, beyond the positive effects, to identify, any weaknesses in the general organization and functioning of the state services for the handling and treatment of other similar problems in the future. In other words the knowledge and experience which was acquired is now a driver for handling any similar crises in the future (Mbrekis 2008, pp. 19-20).

The cooperation between the AF and the OGSD might be described as excellent. This was because the institutional role of AF was clear and specific, aiming in any case at the protection of the State from all external threat as it also aimed at the inviolability of borders. The Ministry of Defense /AF as mentioned before had managed unsuccessfully at a political and at a military level the crisis of IMIA. This case gave a unique opportunity for cooperation with the rest of the security services and bodies in order to plan new projects and test the old ones. At the same time there developed new partnerships with international organizations such as NATO in order to be offered assistance in case Greece asked so (Mbrekis, pp. 169-188). Institutionally it was of the few cases in which a Ministerial Decision was published [Number 1016/114/136- $\alpha^{\prime}$ (B 486)] governing the tasks of the staff of AF who were available for security meters and order during the OG 2004.

For this specific case and in combination with the above, the planning of Olympic security was supported by the general beginnings that compose the operation of management, constituting an administrative organizational model with an effort on distribution of distinguishable roles in all the levels of administration under the supervision of OGSD.

The communication of all institutions in the particular model was supported supposedly by C4I systems.

\subsection{Administrative model}

Lipsky M. (1980), argued that "policy implementation in the end comes down to the people who actually implement it". He argued that state employees such as the police and social workers should be seen as part of the "policy-making community" and as exercisers of political power. Street-level bureaucrats include police officers, firefighters, and others who "walk the streets" with regular citizens, and provide services to protect, as well as uphold the laws. Lipsky identified several problems with street-level bureaucracy, including "the problem of limited resources, the continuous negotiation that is necessary in order to make it seem like one is meeting targets and the relations with (nonvoluntary) clients".

According to Professor Theofanidis St. (1989, p.64) «Management is that specialised human activity which is carried out within an organised collective effort (organization, public service, enterprise etc.) and seeks to achieve to the best possible extent, a desirable outcome (project, sales, servicing, profit etc) with certain functions (planning, organization, staffing etc.) which are used under specific factors (philosophy, general conditions, etc.) and use certain methods or tools (the program, the establishment plan etc).

Tony Evans and John Harris (2004), argued that "the proliferation of rules and regulations should not automatically be equated with greater control over professional discretion; paradoxically, more rules may create more discretion." They also argue that the exercise of professional discretion by street-level bureaucrats is not inherently "bad", but can be seen as an important professional attribute.

Steven Maynard Moody and Musheno M. (2003) of the University of Kansas in an American study conducted in 2003, reiterated the significance of street-level bureaucrats in the political process, asserting that street-level workers "actually make policy choices rather than simply implement the decisions of elected officials." They also claimed, based on a study of 48 street-level state employees in two states, that "workers' beliefs about the 
people they interact with continually rub against policies and rules" and that the prejudices of the street-level bureaucrats influence their treatment of citizens

Noe R., Hollenbeck J., Gerhart B., Wright P., (2006, p.78) claimed that strategic management of human resources is understood as the standard of planned development and allocation of human resources and activities designed to facilitate the achievement of objectives. A strategic decision-making process is understood on strategic direction which determines the consignment and the objectives of a company or organization, the external opportunities, threats and internal strengths and weaknesses. An application planning -no comma) process strategy can understand the structures and allocation of resources for the implementation of the strategy which it has been chosen for by the company.

It is known that the management action consists of the functions of programming, organization, staffing, leadership, coordination, reporting, financial, control and corresponds to the political/strategic level.

The political level for instance was represented by the Cabinet of Foreign and Defense Matters (CFDM) and the Olympic Security Coordinating Council (OSCC). Also at this level the Olympic Preparation Coordination Committee, the Olympic Security Coordination, the Strategy Committee and the Civil Overview body were incorporated. At the Strategic level were the Olympic Centre, the Service Overview Body and the Council of Crisis Management.

It is obvious that these were different levels of administration and it was difficult to coordinate them. In addition, if the centers, which constitute the operational level and the Olympic venues, comprising the tactical level directly, (Table 1 and Figure 1) are taken into account, the difficulty of the administrative model to work was obvious. Also the accumulation of operators at the top of the administrative model showed clearly that the tasks were overlapping.

Tasks overlapping create confusion to the administration, with obvious results as to the urgency in decision-making at the vertical and horizontal reciprocal exchange of information, communication and coordination. In this specific case we are talking about many bodies and services as can be shown in Table 2 .

In support to the above, Kefis V. (2005, p.112) claims that the module administration reflects the principle that each worker must report to a single head who is immediately hierarchically senior. Any overstepping of unity administration leads to conflicts between executives, overstepping control, overlapping responsibilities, time needs and knee-jerk movements in decision-making.

Kefis V. (2005, p.114) claims that coordination is considered as the most difficult operation of management. It is designed to ensure positive, harmonious and effective cooperation between all the components of a body. The executive who will undertake such operations should point to the shortcomings of the differences and conflicts, the wording solutions, the adaptation of human, physical and technical resources with the program of the company and the efficient allocation of powers.

In the case of the planning of OA 2004 a serious point carried out was that the planning was misdirected from the beginning, as the legislative framework laid down that a specific security agency would have a holistic option of the staff and the operational activities of other competent authorities. This institutional responsibility which was entrusted for that period was in conflict with the competences enforced before the OG 2004. Furthermore, it had not the know how to guide properly the actions of other agencies and services and it was possible to be committing an error. The development of high strategy (the highest level of management) would have given incorrect instructions to the middle and to the lower echelons of the security forces. These echelons which apply to all the public policies adopted in specific matters would face increasing confusion, overlapping responsibilities, problems in administration and coordination. The most important was that the security staff should operate in a different institutional basis from the one it had been trained since the orders which were coming from the headquarters level would be incorrect. For instance if a terrorist incident would take place in a port or at the sea (jurisdiction of HCG) and commander of the scene was an officer of HCG, the incident commander was the OSC (HP) and the approval of the operational plans issued by the Head of HCG were approved by the Commander of OSC and then were submitted for final approval to the Head of HP; how would the last two officials then decide? - based on what expertise on projects. In the meanwhile how would the Commander of OSC coordinate operations not only because the C4I did not work but with what experience would it work in a territory unknown to him and with different means of action (for instance floating patrol boat, Special Forces of HCG acting in vessels e.g.). In any case the meaning given to the term coordination as will be analyzed later in the text must be mentioned. 


\section{Decision Making - Legal Framework}

As regards the OGSD under the leadership of HP approved in accordance to article 6 of Presidential Decree (PD) 2/2003 the plans of OGSD after receiving the opinion of the Head of the Hellenic Coast Guard (HCG), the Head of the Hellenic Fire Service (HFS), the representative of AF and the First Deputy Commander of National Intelligence Service (NIS).

A serious point was with what knowledge the leader of HP would have approved projects of other organizations which were specialized in institutional activities. If, for example the Head of HP had a different option at the draft of protection in marine transport which was drawn up by the HCG, according to what know-how would he argue against the Head of a specialized institution?

In Law 2690/1999 ( $\left.\mathrm{A}^{\prime} 45\right)$ and in particular in article 20 is defined what happens in the case in which a previous opinion (simple or positive) is necessary in order for a regulatory action to be published. The specific article in any case did not ensure that if the head of HP did not agree with the proposed draft of an institution would be obliged to publish the issue.

The proper thing for the security of OG 2004 would be for the competent institution to draw up the projects and the final signature/approval of the project should be the responsibility of the natural or political leadership something which did not happen in the planning of OG 2004.

For example, it is mentioned that in exercises which were carried out such as the "ASPIS IRAKLEOUS 2004", it had been requested that the entities contingency plans for various operations (as far as it concerns the HCG many of the plans have had the signature of its Head), be submitted to (Olympic Security Center-OSC) in order that after the approval of its commander, the plans should be submitted for final approval by the Head of HP. Automatically the question arose: what know-how the commander of OSC should have to approve plans of other competent authorities and would the approval by the Head of HP be required while they carried a signature of a leader of another competent authority?

In accordance with article 14 of PD 63/2001 with title 'Relations between the OGSD with other engagement services and operators' the involvement of all the competent authorities in the design and the measures before and during the OG 2004 should have taken place with the responsibility of HP and accordingly to their authorities as these are identified by the analysis and assessment of risks which threatened the OG 2004. The level of involvement of each service and institution was determined by the Director of OGSD after the approval of the political and service overview body.

The interpretation of the word coordination by the HP was another serious point. This was stipulated in accordance with the concept developed at the draft of administration, coordination, control, communications and integration of Olympic Security (C4I), and meant the power which was assigned to a security commander to harmonize the functions or activities in which two or more services of the same or another competency institution were being involved.

In that case, the commander was authorized to coordinate and consult the involved commander of different parties at the proper corresponding level of administration, or their representatives and had the right to impose his/her view, when there was no consensus among them or to submit, during his/her crisis, the matter to a higher level of administration. Therefore, coordination was an indirect form of practice administration. For example OSC, when dealing in order to face different incidents, exercised full operational management of existing police security administration, the Olympic assemblies and installations and in the urban area, in the prefecture of Attica and if there was a reason to do so, in the administrations of the Olympics security cities. Also, to coordinate the responsible authorities which were involved in the incident, in the sense which was indicated by the term of «coordination».

During the enforcement of the operational command of the facts and the coordination of the action of bodies, OSC confirmed that its role was fulfilled and the functions of each institution to deal with the service or body was in accordance with the planning of Olympic security and its institutional authority to act appropriate according to the existing Olympic security administrations in urban areas or at the Olympic cities and through their representative officers toward the responsible bodies, to remove any derogation.

From the combination of the tasks of the Commander of OSC with the tasks of the Specialized Commander Incident (note 5) (individual Commander Incident), is clearly seen that HP had a view in the administration of the forces of other competent authorities which were allocated to the OG 2004. This policy included risk and danger, as well as the officials of HP giving guidelines and instructions for actions to forces of other operators without having the appropriate know-how and experience. 
On the other hand, the responsibilities of each of the competent authorities which took part in the security of the OG 2004 were described clearly on existing provisions. The provision in article 5 of Law 2833/2000 of the general competence of HP for the security of the games, the coordination of the other engagement authorities, as well as the cooperation with them, in no way affected the above specifications in law of the organizations/competent authorities and their right to take decisions under their legal framework, to cooperate for individual issues of which by the same provision was anticipated by the adoption of common ministerial decisions (No 1016/114/108 by 17-10-2003 document of Ministry Of Public Order/Division of Organization and Legislation/ Department 2). It is obvious thus that the system the HP was trying to establish was in confusion.

Theriou N. (2002, p. 26) claims that the purpose of strategic analysis is the way in which the enterprise faces the factors which affect the present and future positive direction, in order to choose the right strategies which would lead to a future development. The understanding of these factors is an important part of the strategy administration and divided into four categories: environment, resources and capabilities which are available by the enterprise, expectations of the interested sides and the culture which dominates the enterprise (the corporate culture).

Xenos D. (2003, p. 18) claims that one of the basic characteristics in an organizational structure of an enterprise should be to avoid multiple fragmentation procedures in complex organizational structures and the clear demarcation and separate responsibilities for any organizational unit in order to avoid emptiness or coatings, delimitation of clear and separate roles, so as to avoid overlapping responsibilities and the gaps accountability.

A crucial role in the design of the Olympic security as well as in the implementation of plans during the OG 2004 and Paralympics Games was had by the key authority OGSD, with the responsibility to coordinate actions of different competent authorities and services with different institutional frameworks, culture, establishment and responsibilities. This inevitably imposed the coexistence of all in order to draw up all the necessary projects and actions with the further purpose to achieve an objective which was the security performance of OG 2004.

Under the united administration of HP, by applying a new model of inter-sectoral cooperation with separate roles and responsibilities at all levels according to a declaration of the Head of HP in a speech on the 16-10-2003 at the Union of Foreign Correspondents Press, could be observed for those who had the right know - how show during the OG 2004-shortcomings, impairment and overlaps whose typical example was on 11-09-2004. On that day the Helicopter make SINOUK fell in the area of ATHO (region in North Greece). As a result of the fall, Alexandros the chief of Priests in Alexandria and another 17 members of the accompanying escort were killed. In the middle of the performance of the Olympic security with the highest possible readiness in all areas, the area of the fall of the helicopter was found with a delay of three hours because the services and the competent authorities could not coordinate and cooperate.

\section{Olympic Security Policy}

In order to achieve the goals of the security program, the following general principles and strategic directions were accepted:

a). The Security of the Olympic Games was part of the security of the Hellenic State, and was not independent of the general policy and security strategy that was planned and applied by the appropriate Hellenic competent authorities.

As mentioned before the provision in article 5 of Law 2833/2000 of the general competence of HP for the security of the games, the coordination of the other engagement operators, as well as the cooperation with them, in no way would affect the above specifications in law of the organizations/competent authorities and their right to take decisions under their legal framework, to cooperate for individual issues of which by the same provision the adoption of common ministerial decisions was anticipated (No 1016/114/108 by 17-10-2003 document of Ministry of Public Order/Division of Organization and Legislation/ Department 2).

Consequently, the Olympic security was part of wider security which was institutionally enforced by the various actors/institutions according to their competence within the scope of the government policy.

The major issue created in this case was how to assign the Olympic security to an institution such as the HP, while HP would have an institutional point of view for actions and responsibilities for operators which were going to work at a parallel security level with entities as HCG. The delivery of opinions and point of view and their imposition later in accordance with the notion of coordination to matters outside its authority in conjunction with the lack of know-how and skills on these, would not create the possibility of enforcement of wrong opinion - decision? For example, what view could HP have in the draft of policing the maritime area, in the draft of the 
Olympic maritime transport, in the draft of the Olympic search and rescue, in the draft of surveillance - policing the maritime borders and national maritime area, etc.

The wording of the document No 1016/114/108 from 17-10-2003 issued by the Ministry of Public Order / Division of Organization and Legislation/Department 2 was moving to the right direction on the basis of the existing legal framework. In contrast to the legal framework created for OG 2004 a mistake was likely to happen because the authority/competence of other operators/competent authorities were not acceptable.

As has been mentioned before the leader of HP was approving in accordance to article 6 of PD 2/2003 the plans of OGSD after the opinion of the Head of the Hellenic Coast Guard, the Head of the Hellenic Fire Service, the representative of A.F., and the First Deputy Commander of NIS.

A serious point was what knowledge would the leader of HP have in order to approve projects of other organizations which were specialized in institutional activities. If, for example the head of HP had a different option at the draft of protection in marine transport which was drawn up by the HCG, according to what know-how would he / she argue against the Head of a specialized institution?

b). The responsibility of the security of the OG rested on the HP, which was going to coordinate all the involved agencies and competent authorities.

Coordination, as has already been mentioned, meant indirect form of administration and was consisting of one of the key dimensions of management. What was mentioned in the previous paragraph applies here. The number of institutions/competent authorities which were involved as can be shown in Table 2 was very large, something which became difficult for the enforcement of coordination by HP.

But also within the OGSD the coordination was difficult, although the target was common, the safe performance of OG 2004. In OGSD personnel from different services were posted. It is obvious that the officials of those competent authorities from different services, different systems of jurisdiction and action, different cultures were difficult to attain constructive cooperation and functionality among them. Different were the role of AF as also the role of NSI. Other officials were public officials and other military officers. But it was a nice try and excellent experience because all the participants should work together for a common purpose.

In addition to the above, the structure of OGSD did not offer flexibility and creativity in the action to the executives who were outside of the HP including the fact that the administration was enforced by HP within the headquarters. Also all the executives were enrolled into to OGSD divisions and departments. The ministerial decisions which were foreseen by article 5 of Law 2833/2000 in accordance with article 14 of PD 63/2001 at least as far as it concerns the HCG were not carried out.

It could be foreseen that the Olympic security extension and implementation of HP functions to the entire country without having the know-how, experience and specialization to manage facts not belonging to its cycle powers of authorities is the outcome. Obviously this, in conjunction with what has been mentioned before entailed risks in the preparation, adoption and implementation of plans.

At the same time new institutions beyond the existing ones at the political level were established, but their authorities were overlapping, making planning difficult, the coordination difficult, difficult the decision-making as well as difficult the forwarding of directives and guidelines to the existing levels.

\section{The OG Constituted Primarily a Sporting Event, and Not a Security Exercise}

There is no doubt that the OG was and still is a major sporting event. The terrorist attacks which occurred during the OG (Munich 1972, Atlanta 1996) irrespective of their incentives, the social demonstration against the commitment of OG of 1968 in Mexico have led to an-increase of security measures, in order to safeguard the performance of the $\mathrm{OG}$ and at the same time to protect the athletes and the spectators.

In particular, following 09/11 the western countries had become targets of islamism fundamentalist organizations -as has been developed in the introduction- a situation leading to them taking additional measures. This last issue meant high expenditure but also the safeguarding of the safe performance of the games which directed to a more than a security exercise, with the use of means and resources to large degrees, carrying out specific trainings and exercises and the maintenance of preparedness at high levels.

The high strategy of Greece for these specific games led to use all the available instruments with a view to maximizing the potential and to minimizing the weaknesses in the field of security. This was the one dimension of the high strategy. The other main dimension was the diagnosis of the international environment (risks opportunities), and here is embodied the study and development of terrorism and asymmetrical threats, during the last years and the upgrading of international cooperation. In this way a positive image was created abroad 
and legitimacy in the internal running, while the safe performance of the OG 2004 was the first political objective of the Hellenic legal order identified with the national interest.

6. The Security of the Games was Based on the Cooperation between Hellenic and International Security Agencies however - at Any Case - Decisions Had to be Taken Only by the Appropriate Hellenic Authorities.

Greece assessed and institutionalized cooperation in international organizations, States, secret services and other law enforcement authorities. In this way, a canopy would have been created effectively which would restrict the opportunities of international terrorism and organized international crime to pass through Greece. Furthermore pressure could be exerted on those countries which had been shown to export crime and create serious compromises in world security.

This context has intensified cooperation with Interpol, Europol and with the police forces in foreign countries. Also there was use of information technology which helped the collection and processing of information. In addition to the cooperation with the United Nations, International Civil Aviation Organization (ICAO) etc coordinating bodies of the European Union were informed while request for assistance was submitted to NATO. Finally cooperation in many areas existed with The Olympic Advisory Team (OAT).

Greece was intended to activate an International Supplementary mechanism providing security. In any case the decisions on all matters were taken by the Hellenic authorities as security belongs to the hard core of state sovereignty.

Human resources that would be used in security duties and measures, would come from the agencies involved in OG security (HP, HCG, HFS, AF, NIS), and each competent authority specifically trained its personnel for that purpose under specific seminars and training courses which had been drafted by the OGSD. In the case of the participation of private agencies or volunteers, their command, training and control would be the responsibility of the main security agency to which they were assigned (Mbrekis Sp., 2008, pp. 139-168). For this purpose the Ministerial Decision number 1016/114/105-E /B 1247 was issued.

\section{Conclusions}

As it was mentioned at the beginning of this short article the aims were to critically discuss the design of the 2004 OG security and in particular the way this had been developed and operated, the operators involved, the management strategy and the administration of the security forces as well as the problems revealed by the enforcement of the relative legislation and the legislation which was established for this specific event.

Based on our analysis we can summarize the following key findings:

The Ministry of Mercantile Marine/HCG had not signed the Law "N. 2833/2000", the PD 63/2001 and the PD $2 / 2003$.

Furthermore, as far as the Ministry of Mercantile Marine/HCG was concerned no Joint Ministerial Decision was issued, as provided for in article 5 of Law "N. 2833/2000", via which the object and that manner of cooperation would be defined, as well as associated matters.

Also while in accordance with article 14 of PD 63/2001 with title "Relations of the OGSD with involved operators and services" it can be shown that the involvement of all the competent authorities and services in the planning of the measures before and during the OG 2004 was the responsibility of HP, and in the light of the provinces of other operators as those identified by the analysis and assessment of risks which threatened the OG 2004, was fixed by the Director of OGSD and then followed approval from the political and services overview body. As regards the MMM/HCG no such procedure had been followed for the degree of involvement.

Although it was a Primary Security Authority, the Hellenic Coast Guard was called after the establishment of the legislation to participate with its officers in the planning of all the kinds of measures and plans under the leadership of the Hellenic Police. It is worth mentioning that the MMM/HCG was not represented at CFDM.

According to article 6 of PD 2/2003, "The plans of the Olympic Games Security Directorate are approved by the Head of the Hellenic Police, after the opinion of the Head of the Coast Guard...". This created an issue, regarding through which knowledge or expertise the Head of the HP would approve plans of other competent authorities, as obviously the Head of the HP was not in a position to have the appropriate know how for specialised activities that each competent authority or agency would develop. If, for example, the Head of Police did not agree on a specific occasion, via which specialised knowledge would, the Police support his point of view? 
Additionally, the fact that the HP had an opinion through the OGSD on matters which were not institutionally or regionally part of its regular purview, created the very real possibility of unforeseen situations developing.

Within the OGSD the coordination was difficult, although the aim was common and that was the secure performance of OG 2004. That was because all competent authorities and services were constituted by different executives (military and / or civilian staff), of different labor status, different culture, philosophy and working conditions.

In addition to the above, the structure of OGSD did not offer flexibility and creativity in action of the executives who were coming from different services except HP, as the administration was enforced by the HP within its headquarters and the executives were enrolled at different departments or deputy divisions.

The existence of multiple levels of command, coupled with the lack of functionality of the C4I system (which was supposed to ensure the immediate dissemination of information), demonstratably delayed the flow of information to the hierarchically higher levels.

From the combination of the tasks of the Commander of Olympic Security Center (OSC) with the tasks of the Specialized Commander Incident (individual Commander Incident), arises clearly that HP had a view in the administration of the forces of other competent authorities and services which were allocated to the OG 2004 This policy concluded risk and dangers, as well as officials of HP who were given guidelines and instructions for actions to forces of other operators without having the appropriate know-how and experience.

The OG 2004 were the first athletic event that took place after the terrorist attack of 09/11 and as has been analyzed in the introduction they were preceded by several other and smaller terrorist attacks, the War of The Gulf and more generally the Islamic-exclusive fundamentalism outbreak. Especially the project for C4I systems with the objective to cover the operational necessities of Olympic security predicted that in every administration level - operational centre would have specific technical and operational opportunities, equipment and abilities, in order to facilitate and affect the receipt of decisions, the administration, the coordination and the control of forces, the equipment and the management of incidents. But these systems

were not received with obvious consequences for the system of control, administration and cooperation.

At the political level, belonged the institutions CFDM, OSCC and the Olympic Preparation Coordination Committee, the Olympic Security Coordination and Strategy Committee and the Civil Overview Body. At strategic level were the Head of the HP the OSCC and the Service Overview Body.

It is obvious that these are different levels of administration and difficult to coordinate- In addition if it is taken into account that the centers which are shown in table 1 constituted the operational level and the Olympic venues constituted the tactical level directly the difficulty can be understood of the working of the administrative model and the accumulation of operators at the top of level whose tasks were overlapping. The overlapping created confusion to the administration, with obvious results to the immediacy in decision-making, in the vertical and horizontal reciprocal exchange of information, and in coordination. The institutions for the control of the Olympic security were too many, while also the OSCC was not necessary as there existed the CFDM.

We observed an over concentration on the authorities of the HP throughout the Hellenic area which leads to a finding that the Olympic security was not part of the state security but identically it covered all the country This power was clearly something beyond the institutional role performed by HP. Foreseen were the Olympic security extension and implementation of its functions to the entire country without having the know-how, experience and specialization to manage facts not belonging to its cycle powers of authorities. Obviously this in conjunction with what has been mentioned entailed risks in the preparation, adoption and implementation of plans.

At the same time new institutions were established beyond the existing at the political level which was the main, but their competences were overlapping, making the planning difficult, difficult the coordination, difficult the decision-making, the contribution of directives and guidelines to the existing levels.

Through the analysis the malfunction of the present organizational model which had been developed in order to cover the necessities of the security of OG 2004 was documented as it had created many levels of administration, had developed many institutions which were involved in the various levels of administration, while there was a lack of communication direct between these levels and the C4I whose main target was the communication between all the levels, to all competent authorities and agencies as has been mentioned, something that did not work. 


\section{References}

Argirakis, A. (2005). The system of C4I doesn't work well and Greece doesn't want to deliver it. Free Press, 5/5/2005, 17.

Elesme. (2006). vol. 33, March - April, 2006.

Evans, T. and Harris, J. (2004). Street-Level Bureaucracy, Social Work and the (Exaggerated) Death of Discretion. British Journal of Social Work, vol. 34, no. 6. http://dx.doi.org/10.1093/bjsw/bch106

Galiatsos, G. (2005). Olympic security and benefits after Olympic Games. Periodic Police Review, vol. 223, 66-73.

Kathimerini, R. (2001). The day in which the world change. International Terrorism. Special Edition 30.09.2001 and 11.09.2001.

Kefis, V. (1998). The management of public enterprises and organisms: systematic approach of his effects in the growth of Greek economy, Interbooks, Athens.

Kefis, V. (2005). Integrated Management. Kritiki, Athens.

King, J. (2002). Bush: Join 'coalition of willing', [Online] Available:http:/edition.cnn.com/2002/WORLD/europe/11/20/prague.bush.nato/ (2010-04-30) .

Konstantinidis, V. The planning of Olympic Security. Periodic police review, vol. 222, pp.11-115.

Laggaris, P. (2003). The comeback of Al Kainta - Greece and the Olympic Games of 2004 - (Is Greece a target ;). Provlimatismoi, vol. 16.

Lipsky, M. (1980). Street-level Bureaucracy. Dilemmas of the Individual in Public Services, 1980.

Manual Olympic Security. (2003). General safety education of staff authorities, Athens.

Maynard, M. S. and Musheno, M. (2003). Cops, Teachers, Counselors: Stories from the Front Lines of Public Service. University of Michigan Press, 2003.

Mbrekis, S. (2008). Olympic Games 2004. The contribution of Greek Armed Forces, Athens.

National Ramparts. (2006), vol. 71.

Noe R, H. J., Gerhard, B. and Wright, P. (2006). Human resource management. Papazisi, Athens.

Ntokos, T. and Tsakonas, P. (2005). Strategic of National Security. Papazisi, Athens.

Platias, Ath. (2002). International Relations and Strategic in Thoukididis. Athens, Estia.

Porter, M. (1980). Competitive Strategy. New York.

Samatas, M. (2007). Security and Surveillance in the Athens 2004 Olympics. Some Lessons from a Troubled Story. International Criminal Justice Review, 3(17):220-238. http://dx.doi.org/10.1177/1057567707306649

Staurakakis, M. (2009). They are trying to close the suspicious folder of C4I. The World of Investment, 3(28-29), 36.

Stavroulakis, P. and Stavroulakis, S. (2008). The technological and legal aspects of communications and information security: a case study of the Olympic Games, Int. J.Technology Transfer and Commercialisation, 1(7), 68-82. http://dx.doi.org/10.1504/IJTTC.2008.018803

Theofanidis, St. (1989). How you will become better priminister, minister, commander. Papazisi, Athens.

Theriou, N. (2002). Strategic Administration of Enterprises. Kritiki, Athens.

Xenos, D. (2003). System for the administration human resources for implementation in businesses and public bodies. Papazisi, Athens.

\section{Notes}

Note 1 . The term asymmetric threat is a modern military term introduced by military analyst's warfare in the past two decades. It is considered the war carried out by organized groups of non-conventional, based on anemia-exception to the rules of law and the law of war, and mainly uses low-cost weapons and operational activity that causes high cost but results in a superior opponent in both human lives and in psychological and social costs. The main purpose of impairment / decline in the determination of the opponent. In asymmetric threats are included the terrorist attacks, guerrilla warfare, organized crime, illegal migration etc. (Ntokos, Tsakonas, 2005, pp. 41-47). 
Note 2. It must be noted that Greece as regards the first war in The Gulf more than the disposal of Navy forces patrolling in the Mediterranean and the availability of all the infrastructures in Greece in order to carry out military missions, in Afghanistan it had provided military forces while in the second Gulf war it had provided facilities to the Allies but it did not participate in war operations. Standing policy of Greece and according to my opinion proper is the implementations of the decisions taken by the UN.

Note 3. In November 2002, U.S. President George W. Bush, visiting Europe for a NATO summit, declared that "should Iraqi President Saddam Hussein choose not to disarm, the United States will lead a coalition of the willing to disarm him."The Bush administration briefly used the term "Coalition of the Willing" to refer to the countries who supported, militarily or verbally, the 2003 invasion of Iraq and subsequent military presence in post-invasion Iraq. (John King, "Bush: Join 'coalition of willing"', CNN. 2002-11-20. Retrieved 2010-04-30).

Note 4. is the natural, technical/technological or other failure /vulnerability associated with the same establishment (by or totally) or in the width region and offers the ability/ advantage to the opponent to act, causing undesirable events and results.

Note 5. The Specialised Event Commander acted as a partial Event Commander, depending on the Command level, his/her institutional responsibility and power, and the mission assigned to him/her by the Head of the Olympic Security Centre, as appropriate.

Table 1. Olympic security command structure ( a legend for the main points as follow)

\begin{tabular}{|c|c|}
\hline GREEK TEXT & ENGLISH \\
\hline A.T. & Police Station \\
\hline АРХНГО $\Sigma$ ГЕЕАА & Head of the Joint Chiefs of Staff \\
\hline АРХНГО $\Sigma \Lambda . \Sigma$. & Head of the Hellenic Coast Guard \\
\hline АРХНГО $\Sigma \Sigma$ & Head of the Hellenic Fire Service \\
\hline A $\Sigma$ TYN. $\Delta / \Sigma E I \Sigma$ & Police Divisions \\
\hline A $\Sigma$ TYNOMIKE $\Sigma$ YПO $\Delta \mathrm{IEY} \Theta Y N \Sigma E I \Sigma$ & Police Sub Divisions \\
\hline 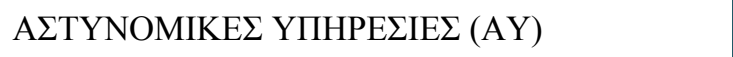 & Police Services \\
\hline 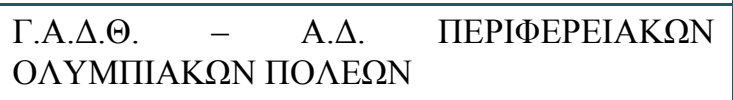 & Police Directorates of Olympic Cities \\
\hline 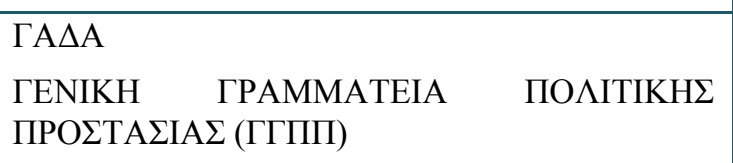 & $\begin{array}{l}\text { General Police Directorate of Attica } \\
\text { General Secretary of Civil Planning }\end{array}$ \\
\hline$\triangle \mathrm{AOA}$ & Olympic Games Security Division \\
\hline$\triangle \mathrm{IAK} \Lambda \mathrm{A} \triangle \mathrm{IKA}$ KENTPA EПIXEIPH $\Sigma \mathrm{E} \Omega \mathrm{N}$ & Joint Operations Centres \\
\hline$\Delta \mathrm{IOIKH} \Sigma \mathrm{H}$ OEOA & $\begin{array}{l}\text { Athens } 2004 \text { Olympic Games Organising } \\
\text { Committee Command }\end{array}$ \\
\hline 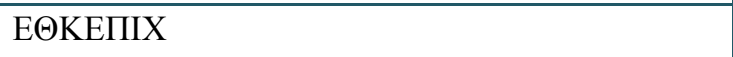 & National Operations Centre \\
\hline EKAB & National Ambulance Centre \\
\hline $\mathrm{EK} \Sigma \mathrm{E} \Delta$ & Joint Search and Rescue Center \\
\hline E $\Lambda . A \Sigma$. & Hellenic Police \\
\hline $\begin{array}{l}\text { ЕПIT. } \Delta \mathrm{IOIK} . \text { OKA, } \Sigma \mathrm{YN} \Delta \mathrm{E} \Sigma \mathrm{MOI} \Phi O P E \Omega N \\
\text { К } \Lambda \Pi\end{array}$ & $\begin{array}{l}\text { Olympic Security Centre Commanders, } \\
\text { Agencies Liaisons, etc. }\end{array}$ \\
\hline ЕҮП / КЕПОА & $\begin{array}{l}\text { National Intelligence Service / Olympic } \\
\text { Games Operations Centre }\end{array}$ \\
\hline
\end{tabular}




\begin{tabular}{|c|c|}
\hline GREEK TEXT & ENGLISH \\
\hline K.E. & Operations Centre \\
\hline К.Е. $\Lambda$ OІПON ФOРЕ $\Omega N$ & Other Agencies Operations Centres \\
\hline $\begin{array}{l}\text { KENTPIKO } \Lambda \text { IMENAPX. ПЕIPAIA } \\
\text { KENTPA } \\
\text { ФOРЕ } \Omega N\end{array}$ & $\begin{array}{l}\text { Piraeus Central Port Authority/Coast } \\
\text { Guard } \\
\text { Command Centers of Different Services }\end{array}$ \\
\hline KENTPO $\Delta \mathrm{IOIKH} \Sigma \mathrm{H} \Sigma \mathrm{A} \Gamma \Omega \mathrm{N} \Omega \mathrm{N}$ & Olympic Games Command Centre \\
\hline$\Lambda . \Sigma$. & Hellenic Coast Guard \\
\hline \IM. TMHMATA & Coast Guard Departments \\
\hline LIMENIKE $\Sigma$ APXE $\Sigma$ & Coast Guard Authorities \\
\hline OEOA & $\begin{array}{l}\text { Athens } 2004 \text { Olympic Games Organising } \\
\text { Committee }\end{array}$ \\
\hline OKA & Olympic Security Centre \\
\hline OKAE & Olympic Venue Security Centre \\
\hline OKAE E $\Lambda$ A $\Sigma$ & $\begin{array}{l}\text { Hellenic Police Olympic Venue Security } \\
\text { Centre }\end{array}$ \\
\hline OKAЕ П $\Lambda \Omega T \Omega N ~ \Xi E N O \triangle O X$. & $\begin{array}{l}\text { Floating Hotels Olympic Venue Security } \\
\text { Centre }\end{array}$ \\
\hline OKE $\Lambda \Sigma$ & $\begin{array}{l}\text { Hellenic Coast Guard Olympic Operations } \\
\text { Centre }\end{array}$ \\
\hline OKЕП & Olympic Intelligence Centre \\
\hline OKЕП $\Sigma$ & $\begin{array}{l}\text { Hellenic Fire Service Olympic Operations } \\
\text { Centre }\end{array}$ \\
\hline ОПКА Е $\Lambda . A \Sigma$. & $\begin{array}{l}\text { Hellenic Police Olympic Regional Security } \\
\text { Centre }\end{array}$ \\
\hline ПА & Hellenic Air Force \\
\hline$\Pi \mathrm{\Pi N}$ & Hellenic Navy \\
\hline$\Pi \mathrm{Y}$ & Hellenic Fire Service \\
\hline $\begin{array}{l}\Sigma Y . \Sigma . O . A . \\
\text { YEN/AГK }\end{array}$ & $\begin{array}{l}\text { Olympic Security Coordinating Council } \\
\text { Ministry of Mercantile Marine/Officer of } \\
\text { General Duties }\end{array}$ \\
\hline इТРАТНГІКО / ПО АІТІКО ЕПІПЕ $\Delta О$ & STRATEGIC / POLITICAL LEVEL \\
\hline 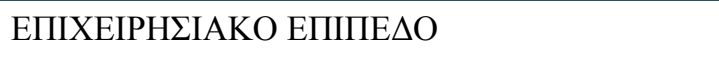 & OPERATIONAL LEVEL \\
\hline ТАКТІКО ЕПІПЕ $\Delta O$ & TACTICAL LEVEL \\
\hline
\end{tabular}

Source: Olympic Games Security Division, 2004 
Table 2. Olympic security agencies involved in the olympic security (The following Ministries and Agencies were involved)

\begin{tabular}{|c|c|}
\hline \multirow[t]{3}{*}{ Ministry of Public Order } & Hellenic Police \\
\hline & Hellenic Fire Service \\
\hline & National Intelligence Agency \\
\hline Ministry of Merchant Marine & Hellenic Coast Guard \\
\hline \multirow[t]{6}{*}{ Ministry of National Defence } & National Defence General Staff \\
\hline & Hellenic Army General Staff \\
\hline & Hellenic Navy General Staff \\
\hline & $\begin{array}{l}\text { Hellenic Air Force General Staff, including the National } \\
\text { Meteorological Service }\end{array}$ \\
\hline & Olympic Health Unit \\
\hline & Ministry of Defence \\
\hline \multicolumn{2}{|l|}{ Ministry of Culture } \\
\hline \multirow{2}{*}{$\begin{array}{l}\text { Ministry of Domestic Affairs, Public } \\
\text { Administration and Decentralisation }\end{array}$} & Organisation of Anti-seismic Planning and Zoning \\
\hline & General Secretariat of Civil Defence \\
\hline \multicolumn{2}{|l|}{$\begin{array}{l}\text { Ministry of Environment, Zoning and } \\
\text { Public Works }\end{array}$} \\
\hline \multirow[t]{3}{*}{ Ministry of Development } & Public Power Corporation \\
\hline & Municipal Natural Gas Corporation of Athens \\
\hline & Hellenic Petroleum Capital Water and Drainage Corporation \\
\hline \multirow[t]{2}{*}{ Ministry of Health and Welfare } & National First Aid Centre \\
\hline & National Health Service Hospitals \\
\hline \multirow[t]{4}{*}{ Ministry of Labour and Social Security } & Organisation of Labour Housing \\
\hline & 10.Ministry of Finance \\
\hline & Customs \\
\hline & Financial and Economic Crime Unit \\
\hline \multicolumn{2}{|l|}{ Ministry of Foreign Affairs } \\
\hline \multirow[t]{5}{*}{ Ministry of Transport and Communications } & Public Telecommunications Company \\
\hline & Civil Aviation Authority \\
\hline & Athens Piraeus Electric Railways \\
\hline & Athens - Piraeus Electric Trolley Company \\
\hline & $\begin{array}{l}\text { Athens Urban Transport Organisation - Thessalonica Urban } \\
\text { Transport Organisation }\end{array}$ \\
\hline \multicolumn{2}{|l|}{$\begin{array}{l}2004 \text { Olympic Games Organising } \\
\text { Committee }\end{array}$} \\
\hline \multirow[t]{5}{*}{$\begin{array}{l}\text { Local (municipal, etc.) Authority } \\
\text { Organisations }\end{array}$} & $\begin{array}{l}\text { City of Athens, and other Cities and Municipalities in the Attica } \\
\text { Prefecture, where Olympic Venues will be situated }\end{array}$ \\
\hline & City of Thessalonica \\
\hline & City of Patra \\
\hline & City of Volos \\
\hline & City of Heraklion \\
\hline
\end{tabular}




\begin{tabular}{|l|l|}
\hline \multirow{5}{*}{ Public Agencies and Corporations } & Municipal Police of Cities and Municipalities involved \\
\cline { 2 - 2 } & Private Hospitals \\
\cline { 2 - 2 } & Private Security Services Companies \\
\cline { 2 - 2 } & Road Assistance Companies \\
\cline { 2 - 2 } & Associations, Volunteer Units \\
\cline { 2 - 2 } & Volunteer Firemen \\
\cline { 2 - 2 } & Hotel Association of Greece \\
\cline { 2 - 2 } & Maritime - Shipping Companies \\
\cline { 2 - 2 } & Air Transport Companies \\
\cline { 2 - 2 } & Taxi Federation of Greece \\
\cline { 2 - 2 } & Tourist Agencies Association \\
\cline { 2 - 2 } & Public Bus Companies \\
\hline Piraeus Port Authority & \\
\hline
\end{tabular}

Source: Olympic Games Security Division, 2004

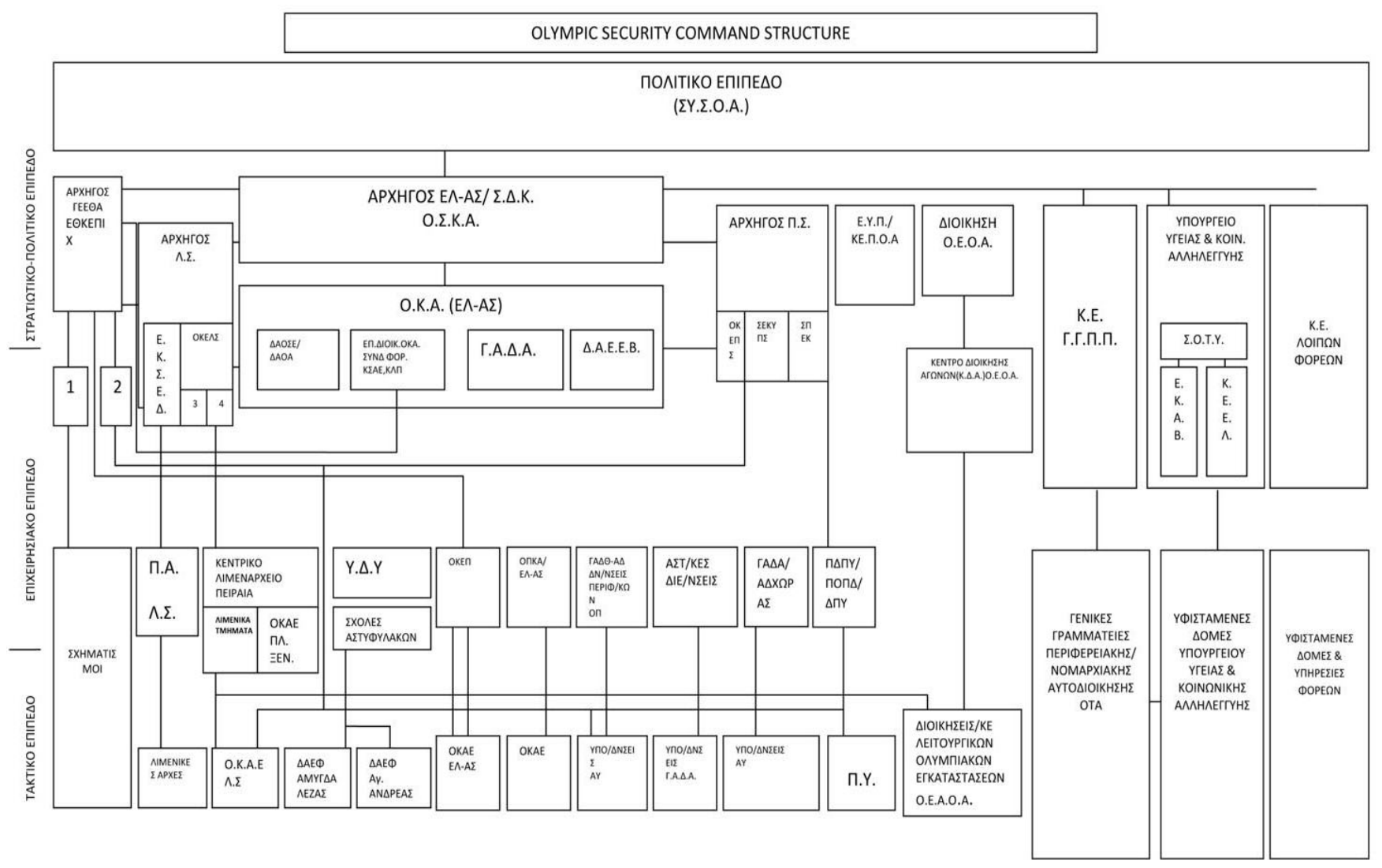

Figure 1. Olympic security command structure 